\title{
Competitive Adsorption of Cadmium(II) and Mercury(II) Ions from Aqueous Solutions by Activated Carbon from Xanthoceras sorbifolia Bunge Hull
}

\author{
Xiaotao Zhang, ${ }^{1,2}$ Yinan Hao, ${ }^{2}$ Ximing Wang, ${ }^{2}$ Zhangjing Chen, ${ }^{3}$ and Chun $\mathrm{Li}^{1}$ \\ ${ }^{1}$ College of Science, Inner Mongolia Agricultural University, Hohhot 010018, China \\ ${ }^{2}$ College of Material Science and Art Design, Inner Mongolia Agricultural University, Hohhot 010018, China \\ ${ }^{3}$ Department of Sustainable Biomaterials, Virginia Tech, Blacksburg, VA 24061, USA \\ Correspondence should be addressed to Ximing Wang; w_ximing@263.net
}

Received 2 August 2016; Revised 15 October 2016; Accepted 19 October 2016

Academic Editor: Yuangen Yang

Copyright (C) 2016 Xiaotao Zhang et al. This is an open access article distributed under the Creative Commons Attribution License, which permits unrestricted use, distribution, and reproduction in any medium, provided the original work is properly cited.

\begin{abstract}
This paper presents low-cost and recyclable activated carbon (XLAC) derived from Xanthoceras sorbifolia Bunge hull for highefficiency adsorption of $\mathrm{Cd}(\mathrm{II})$ and $\mathrm{Hg}$ (II) ions in industrial wastewater. XLAC was prepared through $\mathrm{H}_{3} \mathrm{PO}_{4}$ activation and was characterized using $\mathrm{N}_{2}$ adsorption-desorption, scanning electron microscopy (SEM), energy-dispersive spectroscopy (EDX), and Fourier transform infrared (FTIR) spectroscopy. In single-metal-system adsorption experiments, the maximum adsorption capacities for $\mathrm{Cd}(\mathrm{II})$ and $\mathrm{Hg}(\mathrm{II})$ obtained under different experimental conditions were 388.7 and $235.6 \mathrm{mg} \cdot \mathrm{g}^{-1}$, respectively. All adsorption equilibrium data fit perfectly with the Langmuir isotherm model. In a binary metal system, competitive studies demonstrated that the presence of $\mathrm{Cd}$ (II) significantly decreased the adsorption of $\mathrm{Hg}$ (II), but the adsorption of Cd(II) showed a little change in the presence of $\mathrm{Hg}(\mathrm{II})$. In addition, XLAC can be regenerated with a $0.01 \mathrm{~mol} \cdot \mathrm{L}^{-1} \mathrm{HNO}_{3}$ solution and reused at least four times. The FTIR spectra revealed that a chemical interaction occurs between functional groups containing lone electron pairs in XLAC and metal ions. Overall, these results suggest that XLAC may be suitable as an adsorbent for heavy metal removal from wastewater streams.
\end{abstract}

\section{Introduction}

Water pollution by heavy metal ions is a crucial environmental issue worldwide $[1,2]$ because these ions are acutely toxic, nondegradable, and bioaccumulative. Cadmium(II) and mercury(II) are the most important toxic elements in the liquid wastes of several industries, including those that produce fertilizers, batteries, electronics, textiles, and petrochemicals, as well as tanneries and pesticide mills [3]. The toxicity of $\mathrm{Hg}$ (II) and Cd(II) may lead to carcinogenesis, renal dysfunction, lung damage, and various syndromes in humans. The maximum permitted levels of $\mathrm{Cd}(\mathrm{II})$ and $\mathrm{Hg}(\mathrm{II})$ in livestock wastewater are 2 and $5 \mu \mathrm{g} \cdot \mathrm{L}^{-1}$, respectively [4]. Consequently, effectively controlling the levels of $\mathrm{Hg}$ (II) and $\mathrm{Cd}(\mathrm{II})$ before their disposal into the environment is of great importance [5-7]. At present, conventional technologies widely used to remove heavy metals from industrial effluents and reduce their toxicity include chemical precipitation, liquid extraction, electrolysis, membrane separation, crystallization, and reverse osmosis [8]. Owing to its technical feasibility and cost-effectiveness, adsorption has been universally recognized as an effective and economical method for treating wastewater containing toxic metals [9]. Among the various carbonaceous materials commonly applied for water purification, activated carbon is a promising candidate in the adsorption process owing to its developed porosity, high surface area, large mesopore volume, and low cost and the presence of various functional groups on the surface and its relatively high adsorption rates for heavy metals. The widespread industrial use of activated carbon produced from agricultural waste for the removal of heavy metal contaminants renders activated carbon a high-addedvalue and "green" product that is strongly recommended. Therefore, many studies concerning the preparation of cheap 
and renewable activated carbon from nut shells, fruit stones, biochar, and bamboo culms have been reported [10-14].

In this study, the hull of Xanthoceras sorbifolia Bunge (XL), which is widely distributed in northern China, was utilized in the production of activated carbon (XLAC) because it is an inexpensive and accessible raw material; also, XL has rarely been used as a precursor for activated carbon. XLAC is expected to provide an excellent, highly porous structure and surface functional groups for binding metal ions in wastewater. Industrial contaminants consist of more than one heavy metal ion; thus, by understanding the competition between various metals for adsorption sites on the adsorbents and the interactions under particular conditions during the adsorption process, one can develop applications for real wastewater treatment. Therefore, in the present work, the agricultural-metal-binding XLAC was adopted for the removal of both $\mathrm{Cd}(\mathrm{II})$ and $\mathrm{Hg}(\mathrm{II})$ ions from aqueous solutions.

This study aimed to develop XLAC via $\mathrm{H}_{3} \mathrm{PO}_{4}$ chemical activation and examine its practicality as an adsorbent for the removal of $\mathrm{Cd}(\mathrm{II})$ and $\mathrm{Hg}(\mathrm{II})$ ions from single-metal and binary metal solutions in batch and continuous modes. The physicochemical characteristics of XLAC were investigated using nitrogen adsorption isotherms, scanning electron microscopy (SEM), energy-dispersive X-ray spectroscopy (EDX), and Fourier transform infrared (FTIR) spectroscopy and compared with those of its precursor. The influences of the operating factors were examined to optimize the removal process variables such as the solution $\mathrm{pH}$, initial $\mathrm{Cd}(\mathrm{II})$ and $\mathrm{Hg}$ (II) concentrations, and adsorption temperatures. The results demonstrated that XLAC has great adsorption capacity for both $\mathrm{Cd}(\mathrm{II})$ and $\mathrm{Hg}(\mathrm{II})$ ions. Additionally, isotherm equilibrium parameters were calculated by applying models to the experimental data. Furthermore, the novelty of this paper lies in its evaluation of the competitive adsorption of $\mathrm{Cd}(\mathrm{II})$ and $\mathrm{Hg}(\mathrm{II})$ from a binary system; both ions are categorized in the II Deputy Group, in the fifth and sixth periods of the periodic table, respectively, but have different ionic radii and valence electron arrangements. The results showed that XLAC can remove $\mathrm{Cd}(\mathrm{II})$ ions from solution more efficiently than it can remove $\mathrm{Hg}$ (II). XLAC was evaluated for its applicability. Additionally, the potential adsorption amounts and possible mechanisms of Cd(II) and $\mathrm{Hg}(\mathrm{II})$ ion uptake in XLAC were investigated.

\section{Materials and Methods}

2.1. Materials. X. sorbifolia Bunge hull (XL) was obtained from the solid waste disposal site of a marketplace located in Chifeng, China; it was then dried and screen-sieved. The portion with particle diameters in the $0.50-0.80 \mathrm{~mm}$ range was selected for the preparation of activated carbon. $\mathrm{Cd}\left(\mathrm{NO}_{3}\right)_{2} \cdot 4 \mathrm{H}_{2} \mathrm{O}$ and $\mathrm{Hg}\left(\mathrm{NO}_{3}\right)_{2} \cdot \mathrm{H}_{2} \mathrm{O}$ were purchased from Beijing Chemical Works, Beijing, China. Calibration curves of the examined ions were established using standard solutions of $\mathrm{Cd}(\mathrm{II})$ and $\mathrm{Hg}(\mathrm{II})$ prepared in $0.5 \mathrm{~mol} \cdot \mathrm{L}^{-1} \mathrm{HNO}_{3}$ by diluting initial stock solutions $\left(1000 \mathrm{mg} \cdot \mathrm{L}^{-1}\right)$. All of the other chemicals used in this study were of analytical grade, were used without further purification, and were supplied by Tianjin Bodi Chemical Reagent Co., Ltd., China. All of the solutions were prepared with deionized redistilled water.

2.2. Buffer Solution. First, $3.4 \mathrm{~g}(0.025 \mathrm{~mol})$ of sodium acetate trihydrate $(\mathrm{NaOAc})$ and $1.5 \mathrm{~mL}(0.025 \mathrm{~mol})$ of glacial acetic acid (HOAc) were mixed and placed in a $2 \mathrm{~L}$ volumetric flask. The mixture was diluted to scale with deionized redistilled water to prepare a buffer of $\mathrm{pH}$ 4.84. Furthermore, the $\mathrm{NaOAc} / \mathrm{HOAc}$ buffer solution and $\mathrm{NaOH}(0.1$ and $0.01 \mathrm{~mol} \cdot \mathrm{L}^{-1}$ ) were used to adjust the $\mathrm{pH}$ values of the solutions.

2.3. Preparation of XLAC. The XL was washed to neutrality with deionized redistilled water and sun-dried for $12 \mathrm{~h}$ until all of the moisture evaporated. Next, the sample was oven-dried at $100^{\circ} \mathrm{C}$ for $24 \mathrm{~h}$. The dried mass was mixed with a $45 \mathrm{wt} . \% \mathrm{H}_{3} \mathrm{PO}_{4}$ solution at a ratio of $2.6: 1$ ( $\mathrm{g} \mathrm{H}_{3} \mathrm{PO}_{4} / \mathrm{g} \mathrm{XL}$ ) and the mixture was magnetically stirred (500 revolutions $\cdot \mathrm{min}^{-1}$ ) for $1 \mathrm{~h}$. Afterwards, the impregnated sample was allowed to carbonize at $500^{\circ} \mathrm{C}$ in a tube furnace (FSX2-12-15N, Tianjin, China) for $1 \mathrm{~h}$. After cooling to room temperature under nitrogen atmosphere, the sample was rinsed with deionized redistilled water until neutral $\mathrm{pH}$ was attained. The sample was then oven-dried overnight at $120^{\circ} \mathrm{C}$ to a constant weight, and the yield was evaluated. Yields of $34 \%$ were attained. The developed $X$. sorbifolia Bunge hull activated carbon is hereafter denoted as XLAC. Finally, the XLAC was ground, sieved at 200 mesh by standard sieves (Model Ф200), and kept in an airtight packet for batch experiments.

2.4. Properties of XLAC. The Brunauer-Emmett-Teller (BET) surface area of the XLAC was determined from nitrogen adsorption-desorption isotherms measured at $-196^{\circ} \mathrm{C}$ using a surface area analyzer (Micromeritics ASAP 2020, USA). The pore structure of the XLAC was assessed from the isotherms according to conventional procedures. The surface area $\left(S_{\mathrm{BET}}\right)$ and total pore volume $\left(V_{\text {tot }}\right)$ were determined using the manufacturer's software. The micropore surface area $\left(S_{\text {mic }}\right)$ and mesopore surface area $\left(S_{\text {meso }}\right)$, as well as the mesopore volume $\left(V_{\text {meso }}\right)$, were evaluated using the t-plot method. The density functional theory pore size distribution of the XLAC was obtained using the Autosorb software package with medium regularization. SEM was performed to visualize the morphological changes and to analyze the surface of the XLAC, and elemental analysis of the XLAC was performed using EDX coupled with SEM (Hitachi S3400, Japan). The surface functionalities of the XL and XLAC were identified using FTIR spectroscopy (Thermo Nicolet, NEXUS, TM, USA). The spectra were recorded using the transmission method. Each sample was ground in $\mathrm{KBr}$ at a mass ratio of $1: 200$, and the resulting mixture was pressed.

2.5. Batch Adsorption Experiments. Stock solutions with concentrations of $0.01 \mathrm{~mol} \cdot \mathrm{L}^{-1}$ were prepared by dissolving the necessary amounts of $\mathrm{Cd}(\mathrm{II})$ and $\mathrm{Hg}$ (II) ions in deionized redistilled water and diluting to the desired concentrations. 
A series of adsorption experiments were conducted by combining $50 \mathrm{mg}$ of XLAC with $50 \mathrm{~mL}$ of $\mathrm{Cd}$ (II) and $\mathrm{Hg}$ (II) solutions at different initial concentrations ranging from 0.0035 to $0.0065 \mathrm{~mol} \cdot \mathrm{L}^{-1}$ and $\mathrm{pH}$ values ranging from 2.5 to 6.0. Each metal ion solution was added to capped Erlenmeyer flasks that were placed in a thermostatic shaker (SHA-C, Jiangsu, China) and shaken at a constant speed of 200 revolutions $\cdot \mathrm{min}^{-1}$ at $40^{\circ} \mathrm{C}$ for $300 \mathrm{~min}$ until equilibrium. Next, the $\mathrm{pH}$ of the suspension was adjusted with a certain amount of buffer solution and monitored using a $\mathrm{pH}$ meter (PB-10, Sartorius, Germany). Afterwards, all of the samples were centrifuged at 6000 revolutions $\cdot \mathrm{min}^{-1}$ for $10 \mathrm{~min}$. The initial and residual $\mathrm{Cd}(\mathrm{II})$ and $\mathrm{Hg}(\mathrm{II})$ concentrations were measured using an ultraviolet- (UV-) visible spectrophotometer [15] (TU-1901, Beijing, China). The Cd(II) and $\mathrm{Hg}$ (II) ion concentrations were calculated from the measured absorbance in the upper fluid at their corresponding maximum absorption wavelengths $\left(\lambda_{\max }\right.$ of $\mathrm{Cd}(\mathrm{II})=578 \mathrm{~nm}$ and $\lambda_{\max }$ of $\left.\mathrm{Hg}(\mathrm{II})=490 \mathrm{~nm}\right)$. Spectroscopic grade standards were periodically checked during the experiment and used to calibrate the instrument $\left(R^{2} \geq 0.9990\right)$. Taking experimental errors into consideration, each determination was repeated three times in parallel under the same conditions, and the average values are given in this manuscript. The adsorption capacities for $\mathrm{Cd}(\mathrm{II})$ and $\mathrm{Hg}(\mathrm{II})$ were calculated from [16]

$$
\begin{aligned}
& q_{t, 1}=\frac{\left(C_{0,1}-C_{t, 1}\right) V_{1} \times 112.4}{m_{1}}, \\
& q_{t, 2}=\frac{\left(C_{0,2}-C_{t, 2}\right) V_{2} \times 200.6}{m_{2}},
\end{aligned}
$$

where $q_{t, 1}$ and $q_{t, 2}\left(\mathrm{mg} \mathrm{g}^{-1}\right)$ represent the adsorption capacities for $\mathrm{Cd}(\mathrm{II})$ and $\mathrm{Hg}(\mathrm{II})$ at time $t(\mathrm{~min}), C_{0,1}$ and $C_{t, 1}$ $\left(\mathrm{mol} \cdot \mathrm{L}^{-1}\right)$ represent the initial and final concentrations of $\mathrm{Cd}(\mathrm{II})$ at time $t(\mathrm{~min})$, and $C_{0,2}$ and $C_{t, 2}\left(\mathrm{~mol} \cdot \mathrm{L}^{-1}\right)$ represent the initial and final concentrations of $\mathrm{Hg}$ (II) at time $t$ ( $\mathrm{min}$ ), respectively. $V_{1}$ and $V_{2}(\mathrm{~mL})$ represent the volumes of the $\mathrm{Cd}(\mathrm{II})$ and $\mathrm{Hg}$ (II) solutions. $m_{1}$ and $m_{2}(\mathrm{~g})$ are the masses of the adsorbents. In the calculations of $q_{t, 1}$ and $q_{t, 2}$, no losses of $\mathrm{Cd}(\mathrm{II})$ and $\mathrm{Hg}$ (II) to any other mechanism (e.g., volatilization, sorption to the glassware, or degradation) were assumed.

2.6. Adsorption Isotherms. Equilibrium adsorption experiments were performed by combining $50 \mathrm{mg}$ of XLAC with $50 \mathrm{~mL}$ of heavy metal solutions at different initial concentrations $\left(0.0035-0.0065 \mathrm{~mol} \cdot \mathrm{L}^{-1}\right)$ and different temperatures $\left(35^{\circ} \mathrm{C}, 40^{\circ} \mathrm{C}\right.$, and $\left.45^{\circ} \mathrm{C}\right)$ until adsorption equilibrium was reached. The Langmuir and Freundlich isotherm models for single-metal systems were used to determine the adsorption equilibrium [17].

2.7. Competitive Adsorption. In this step, $50 \mathrm{mg}$ of XLAC was added to synthetic mixtures of primary and secondary Cd(II) and $\mathrm{Hg}(\mathrm{II})$ solutions. Adsorption equilibrium experiments were conducted as described previously to measure the adsorption capacity for $\mathrm{Cd}(\mathrm{II})$ ions at equilibrium (initial
Cd(II) concentration ranged from 0.0035 to $0.0065 \mathrm{~mol} \cdot \mathrm{L}^{-1}$ ) in the presence of $0.005 \mathrm{~mol} \cdot \mathrm{L}^{-1} \mathrm{Hg}(\mathrm{II})$ ions in solution; likewise, the adsorption capacity for $\mathrm{Hg}$ (II) ions at adsorption equilibrium (initial $\mathrm{Hg}$ (II) concentration ranged from 0.0035 to $0.0065 \mathrm{~mol} \cdot \mathrm{L}^{-1}$ ) was determined in the presence of $0.005 \mathrm{~mol} \cdot \mathrm{L}^{-1} \mathrm{Cd}(\mathrm{II})$ ions in solution. The binary metal solutions were agitated at a constant speed of 200 revolutions $\cdot \mathrm{min}^{-1}$ at $\mathrm{pH} 5.5$ for $300 \mathrm{~min}$ until equilibrium. The Cd(II) and $\mathrm{Hg}$ (II) concentrations in the individual binary solutions were determined using a UV-visible spectrophotometer.

2.8. Regeneration Studies. The studies on the regeneration of $\mathrm{Cd}(\mathrm{II})$ and $\mathrm{Hg}(\mathrm{II})$ ions from XLAC were performed in $100 \mathrm{~mL}$ flasks using $0.01 \mathrm{~mol} \cdot \mathrm{L}^{-1} \mathrm{HNO}_{3}$. The metal-ion-loaded XLAC reacted with the $\mathrm{HNO}_{3}$ eluent solution for $120 \mathrm{~min}$, and then the mixture was filtered; then, the XLAC was washed with deionized water to neutral $\mathrm{pH}$, dried, and reused for the next adsorption process. Adsorption-desorption experiments were performed five times consecutively.

\section{Results and Discussion}

3.1. Characterization of XLAC. $\mathrm{N}_{2}$ adsorption-desorption isotherms for XLAC and the precursor, XL, are displayed in Figure 1(a), and they reveal that XLAC shows a mixture isotherm characteristic of type I and type IV [18]. The adsorption volume of XLAC increased with the relative pressure until $p / p_{0} \approx 0.45$, with a wider hysteresis loop at relatively high pressures, indicating the presence of many mesopores. The textural parameters of XLAC in Table 1 show that its surface area and total pore volume were higher than those of XL, at $688.62 \mathrm{~m}^{2} \cdot \mathrm{g}^{-1}$ and $0.377 \mathrm{~cm}^{3} \cdot \mathrm{g}^{-1}$, respectively. These results imply that the contribution of the mesopores to the total pore volume $(66.8 \%)$ became dominant and that the porous structure of XLAC was well developed. As reported for the activation process of XLAC, there may have been some reactions between $\mathrm{H}_{3} \mathrm{PO}_{4}$ and the internal functional groups of XL, causing pore volume enhancement and expansion [19].

Figure 1(b) shows the pore size distribution of XLAC. XLAC has pore sizes between 0.5 and $5.5 \mathrm{~nm}$ and shows a wide pore size distribution with a low pore volume. Table 1 also shows that the mesopore surface area increased notably. Thus, a significant amount of micropores became mesopores.

Elemental analysis was conducted for XLAC and XL using EDX. As indicated in Table 2, the carbon, oxygen, nitrogen, and phosphorus contents of XLAC were $80.26 \%, 12.92 \%$, $4.62 \%$, and $2.20 \%$, respectively. Additionally, XLAC prepared from $\mathrm{XL}$ using the activating reagent, $\mathrm{H}_{3} \mathrm{PO}_{4}$, during the treatment process showed a higher carbon content $(80.26 \%)$ than XL (59.41\%). Moreover, the appearance of elemental phosphorus (2.20\%), due to the introduction of $\mathrm{H}_{3} \mathrm{PO}_{4}$ to be reacted with $\mathrm{XL}$ during the activation process, was confirmed by EDX analysis.

The surface morphologies of XLAC and XL were investigated using SEM and are shown in Figure 1. For XL (Figure 1(c)), the surface was irregular in nature, with many small sheets or layers with large pores. XLAC (Figure 1(d)) 


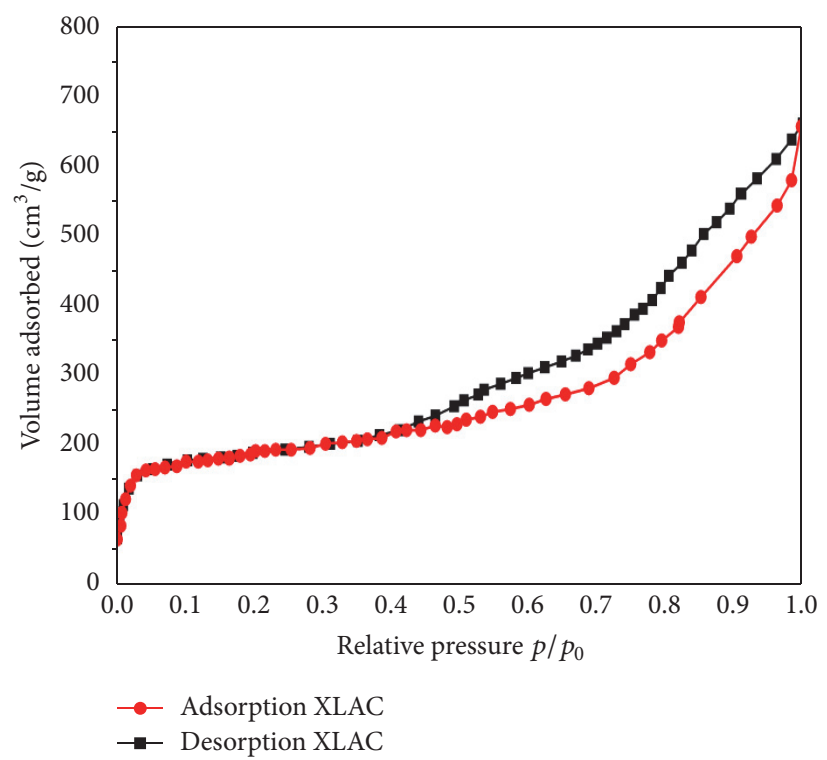

(a)

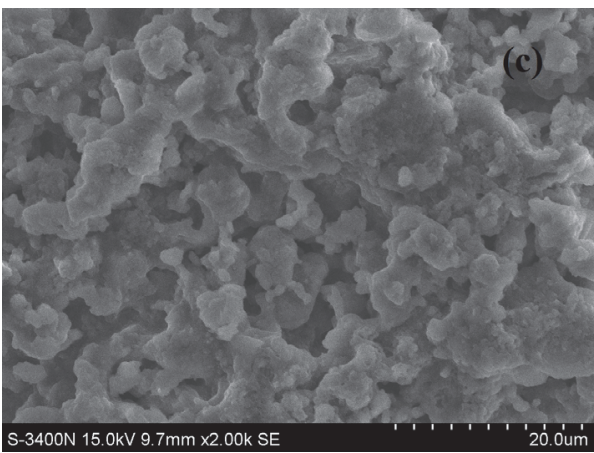

(c)

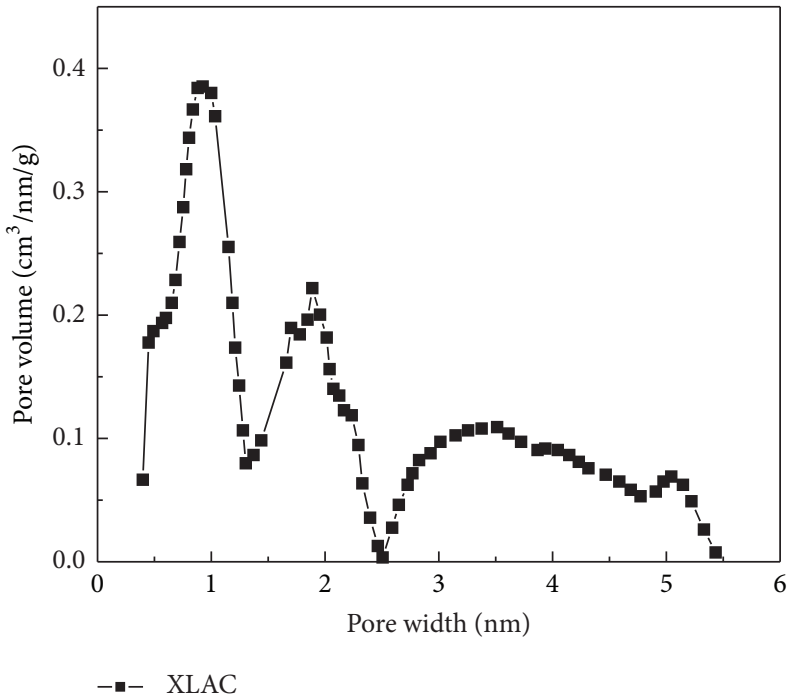

(b)

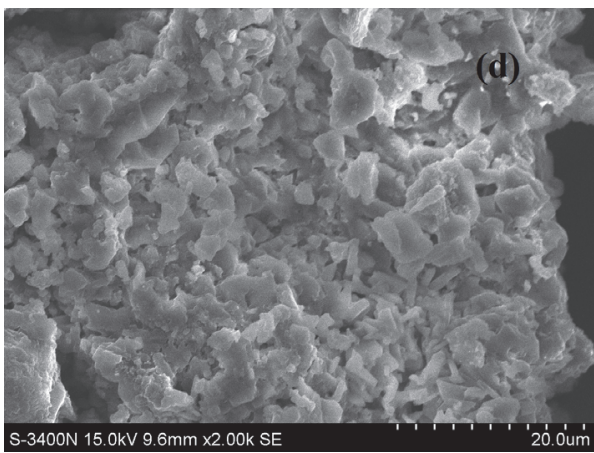

(d)

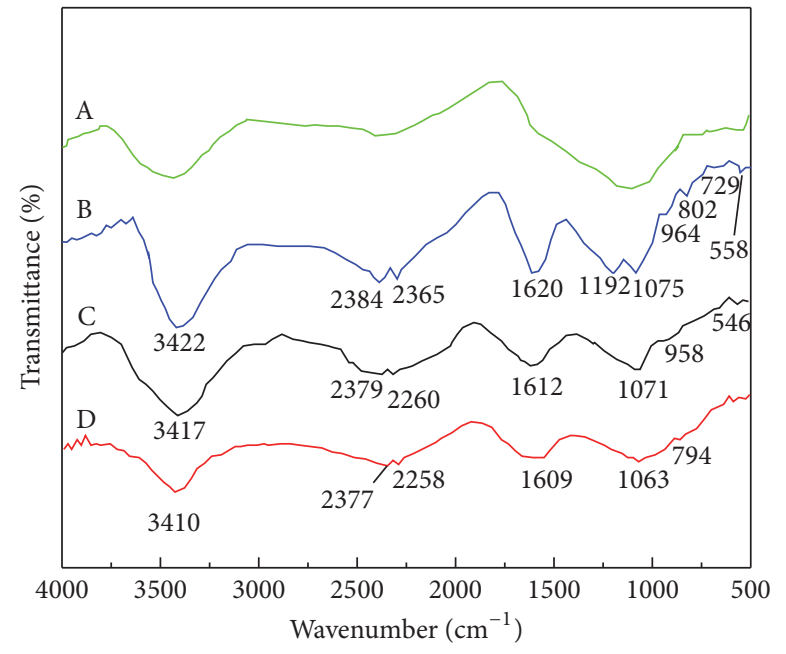
A: XL
C: $\mathrm{Hg}(\mathrm{II})$-loaded
B: XLAC
D: Cd(II)-loaded

(e)

Figure 1: (a) Nitrogen adsorption (circle) and desorption (square) isotherms at $-196^{\circ} \mathrm{C}$ on the activated carbon (XLAC) samples. (b) Pore size distribution of XLAC samples. (c) SEM microphotograph of XL at 2000x magnification. (d) SEM microphotograph of XLAC at 2000x magnification. (e) FTIR spectra of XL and XLAC after adsorption of Cd(II) and $\mathrm{Hg}$ (II). 
TABLE 1: Pore structure parameters of XLAC and XL.

\begin{tabular}{lccccccc}
\hline Sample & $S_{\text {BET }}\left(\mathrm{m}^{2} \cdot \mathrm{g}^{-1}\right)$ & $S_{\text {meso }}\left(\mathrm{m}^{2} \cdot \mathrm{g}^{-1}\right)$ & $S_{\text {mic }}\left(\mathrm{m}^{2} \cdot \mathrm{g}^{-1}\right)$ & $V_{\text {tot }}\left(\mathrm{cm}^{3} \cdot \mathrm{g}^{-1}\right)$ & $V_{\text {meso }}\left(\mathrm{cm}^{3} \cdot \mathrm{g}^{-1}\right)$ & $V_{\text {meso }} / V_{\text {tot }}(\%)$ & $D_{p}(\mathrm{~nm})$ \\
\hline XLAC & 688.62 & 477.87 & 210.43 & 0.377 & 0.252 & 66.8 \\
XL & 16.54 & 14.98 & - & 0.008 & 0.005 & 62.5 \\
\hline
\end{tabular}

Number of analyses: three.

$S_{\mathrm{BET}}$ : specific surface area; $S_{\text {meso }}:$ mesopore surface area; $S_{\text {mic }}:$ micropore surface area; $V_{\text {tot }}:$ total pore volume; $V_{\text {meso }}:$ mesopore volume; $V_{\text {meso }} / V_{\text {tot }}:$ ratio of mesopore volume to total pore volume; $D_{p}$ : average pore size.

TABLE 2: Global surface composition as determined by EDX analysis.

\begin{tabular}{lccccccc}
\hline Sample & C (at.\%) & O (at.\%) & N (at.\%) & P (at.\%) & O/C (\%) & N/C (\%) & P/C (\%) \\
\hline XLAC & 80.26 & 12.92 & 4.62 & 2.20 & 16.1 & 0.07 & 0.03 \\
XL & 59.41 & 29.53 & 3.22 & 0.07 & 49.7 & 0.05 & 0.001 \\
\hline
\end{tabular}

CONP: contributions (at.\%) of carbon, oxygen, nitrogen, and phosphorus; O/C: ratio of oxygen to carbon; N/C: ratio of nitrogen to carbon; P/C: ratio of phosphorus to carbon.

exhibited a coarse and microporous structure comprising a considerable amount of small cavities on the surface [20]. This morphology suggests a rearrangement of the structure during the activation process, indicating a higher surface area and successful pore development in the XLAC.

FTIR spectroscopy was employed to evaluate the changes in the major functional groups of XLAC and XL, and the results are shown in Figure 1(e). In contrast to XL (Figure 1(e)(A)), the broad overlapping absorption band at $3300-3500 \mathrm{~cm}^{-1}$ was due to the stretching vibration of the hydroxyl $(-\mathrm{OH})$ and amine $(-\mathrm{NH})$ groups on XLAC, with a maximum at $3422 \mathrm{~cm}^{-1}$ (Figure $1(\mathrm{e})(\mathrm{B})$ ); this peak shifted to 3417 and $3410 \mathrm{~cm}^{-1}$ after the adsorption of $\mathrm{Cd}(\mathrm{II})$ and $\mathrm{Hg}(\mathrm{II})$, respectively, and shrank (Figure $1(\mathrm{e})(\mathrm{C}$ and D)). These changes in the absorption bands illustrate that the $-\mathrm{OH}$ and - $\mathrm{NH}$ on a multimer differed from those on a monopolymer or even in a dissociative state, indicating that the states of $-\mathrm{OH}$ and $-\mathrm{NH}$ were affected by binding with $\mathrm{Cd}(\mathrm{II})$ and $\mathrm{Hg}$ (II). The peaks at 2384 and $2265 \mathrm{~cm}^{-1}$ were related to the $\mathrm{C}-\mathrm{H}$ stretching in the methyl groups (Figure 1(e)(B)) and shifted after adsorption (Figure $1(\mathrm{e})(\mathrm{C}$ and $\mathrm{D})$ ). A new intense peak at approximately $1620 \mathrm{~cm}^{-1}$, which was assigned to the $-\mathrm{C}=\mathrm{O}$ stretching vibration in the carboxyl groups, appeared (Figure 1(e)(B)) and was shifted significantly to 1612 and $1609 \mathrm{~cm}^{-1}$ and shrank (Figure $1(\mathrm{e})(\mathrm{C}$ and D)). The peak appearing at $1192 \mathrm{~cm}^{-1}$ (Figure $1(\mathrm{e})(\mathrm{B})$ ) was assigned to $\mathrm{P}=\mathrm{O}$ because $\mathrm{H}_{3} \mathrm{PO}_{4}$ was used as the activating agent, leading to the formation of phosphate acid esters. Furthermore, the peak at $1075 \mathrm{~cm}^{-1}$ corresponded to the $\mathrm{C}-\mathrm{O}$ stretching in saturated aliphatic groups, and the $-\mathrm{C}-\mathrm{O}$ and $-\mathrm{O}-\mathrm{C}=\mathrm{O}$ stretching of the carboxyl groups broadened, shrank, and shifted to $1071 \mathrm{~cm}^{-1}$ after $\mathrm{Hg}(\mathrm{II})$ adsorption (Figure $1(\mathrm{e})(\mathrm{C})$ ) and $1063 \mathrm{~cm}^{-1}$ after Cd(II) adsorption (Figure $\left.1(\mathrm{e})(\mathrm{D})\right)$. The peaks at approximately 964,802 , and $729 \mathrm{~cm}^{-1}$ were assigned to the $-\mathrm{C}-\mathrm{H}$ of the benzene ring and aromatic alcohols, and the band at $558 \mathrm{~cm}^{-1}$ may be assigned to the out-of-plane bending of $\mathrm{C}-\mathrm{O}$ bonds of alcohols and $\mathrm{C}-\mathrm{N}$ bonds of amides; these peaks shrank after adsorption (Figure 1(e)(C and D)). These changes in the absorption peaks indicate that the free carboxyl groups became carboxylates, which appeared during the adsorption reaction between the metal ions and XLAC. Additionally, ion exchange occurred, and chemical bonds were formed between the metal ions and the $-\mathrm{OH}$, $-\mathrm{NH},-\mathrm{C}=\mathrm{O}$, and $-\mathrm{O}-\mathrm{C}=\mathrm{O}$ groups of the XLAC. Generally, the bands show that the XLAC surface was provided with a certain amount of activated functional groups in the adsorption process $[21,22]$.

3.2. Effect of $p H$. The $\mathrm{pH}$ value of the heavy metal solution plays a major role in the adsorption process. The influence of $\mathrm{pH}$ on the adsorption capacity of XLAC was studied over the 2.5-6.0 $\mathrm{pH}$ range in the single-metal system, and the results are shown in Figure 2(a). The adsorption capacity of XLAC

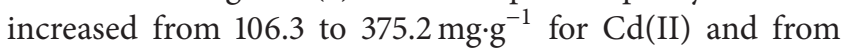
81.2 to $228.7 \mathrm{mg} \cdot \mathrm{g}^{-1}$ for $\mathrm{Hg}(\mathrm{II})$ when the $\mathrm{pH}$ was increased from 2.5 to 6.0 . When the $\mathrm{pH}$ value was low, the overall surface charge of the activated sites became positive, and $\mathrm{H}^{+}$could compete with metal ions for exchangeable cations, resulting in lower uptake of $\mathrm{Cd}(\mathrm{II})$ and $\mathrm{Hg}$ (II) [23]. The XLAC surface became more negatively charged as the $\mathrm{pH}$ increased, and because of the weak competition effect of the $\mathrm{pH}$, more positively charged metal ions were adsorbed. Decreases in the adsorption capacity at higher $\mathrm{pH}$ values were related not only to the formation of $\mathrm{Cd}(\mathrm{OH})_{2}$ and $\mathrm{Hg}(\mathrm{OH})_{2}$, but also to the ionized nature of the functional groups on the XLAC surface. The maximum adsorptions were observed at 5.1 for Cd(II) and 4.5 for $\mathrm{Hg}(\mathrm{II})$ ions; therefore, the $\mathrm{pH}$ value was adjusted to 5.5 for the remaining adsorption experiments.

3.3. Effect of Initial Concentrations. To evaluate the adsorbability of $\mathrm{Cd}(\mathrm{II})$ and $\mathrm{Hg}(\mathrm{II})$ on XLAC, the adsorption capacities towards $\mathrm{Cd}$ (II) and $\mathrm{Hg}$ (II) ions were determined in single-metal solutions. Figure 2(b) shows the effects of the concentration of each metal, which ranged from 0.0035 to $0.0065 \mathrm{~mol} \cdot \mathrm{L}^{-1}$ at $\mathrm{pH} 5.5$, on the adsorption capacity of XLAC. The adsorption capacity of XLAC increased from 264.3 to $381.1 \mathrm{mg} \cdot \mathrm{g}^{-1}$ for $\mathrm{Cd}(\mathrm{II})$ and from 206.2 to $235.6 \mathrm{mg} \cdot \mathrm{g}^{-1}$ for $\mathrm{Hg}(\mathrm{II})$ ions with an increase in the metal ion concentration, gradually reaching adsorption equilibrium. When the initial concentration was low, the activated 


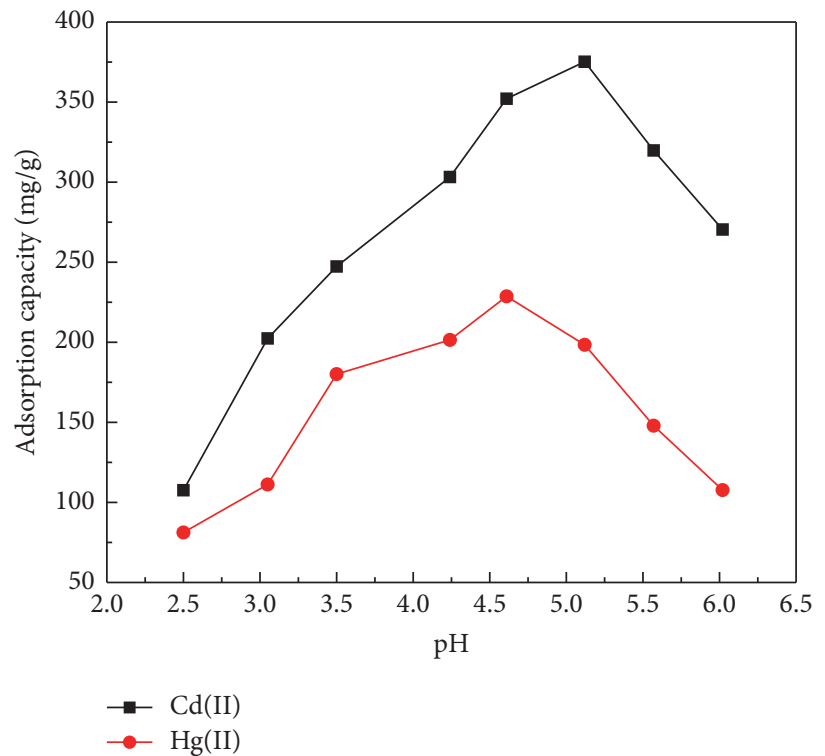

(a)

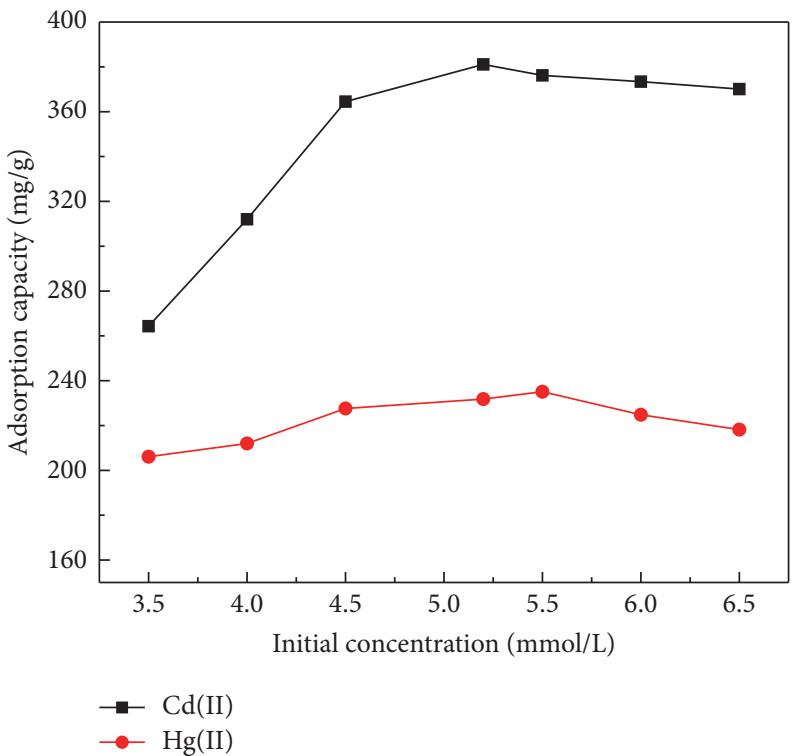

(b)

FIGURE 2: (a) Effects of different $\mathrm{pH}$ values on the adsorption of $\mathrm{Cd}(\mathrm{II})$ and $\mathrm{Hg}$ (II) ions by XLAC (adsorption experiments, Cd(II): $m=$ $50 \mathrm{mg}, V=50 \mathrm{~mL}, C_{0(\mathrm{Cd}(\mathrm{II}))}=0.01 \mathrm{~mol} \cdot \mathrm{L}^{-1}, T=40^{\circ} \mathrm{C}, t=300 \mathrm{~min}$, revolution rate $=200$ revolutions $\cdot \mathrm{min}^{-1}$, and $\mathrm{pH}$ values ranged from 2.5 to 6.0; $\mathrm{Hg}(\mathrm{II}): m=50 \mathrm{mg}, V=50 \mathrm{~mL}, C_{0(\mathrm{Hg}(\mathrm{II}))}=0.01 \mathrm{~mol} \cdot \mathrm{L}^{-1}, T=40^{\circ} \mathrm{C}, t=300 \mathrm{~min}$, revolution rate $=200$ revolutions $\cdot \mathrm{min}^{-1}$, and $\mathrm{pH}$ values ranged from 2.5 to 6.0). (b) Effects of different initial metal ion concentrations on the adsorption of Cd(II) and Hg(II) by XLAC (adsorption experiments, $\mathrm{Cd}(\mathrm{II}): m=50 \mathrm{mg}, V=50 \mathrm{~mL}, \mathrm{pH}=5.5, T=40^{\circ} \mathrm{C}, t=300 \mathrm{~min}$, revolution rate $=200$ revolutions $\cdot \mathrm{min}^{-1}$, and $C_{0(\mathrm{Cd}(\mathrm{II}))}$ ranged from 0.0035 to $0.0065 \mathrm{~mol} \cdot \mathrm{L}^{-1} ; \mathrm{Hg}(\mathrm{II}): m=50 \mathrm{mg}, V=50 \mathrm{~mL}, \mathrm{pH}=5.5, T=40^{\circ} \mathrm{C}, t=300 \mathrm{~min}$, revolution rate $=200 \mathrm{revolutions} \cdot \mathrm{min}^{-1}$, and $\mathrm{C}_{0(\mathrm{Hg}(\mathrm{II}))}$ ranged from 0.0035 to $\left.0.0065 \mathrm{~mol} \cdot \mathrm{L}^{-1}\right)$.

adsorption sites on XLAC were sufficient. Afterwards, as the concentration of $\mathrm{Cd}(\mathrm{II})$ and $\mathrm{Hg}(\mathrm{II})$ increased, more available functional sites became occupied until saturation, causing the adsorption capacity to remain nearly constant. Nevertheless, the adsorption capacities for $\mathrm{Cd}$ (II) and $\mathrm{Hg}$ (II) differed, as shown in Figure 2(b); for a given XLAC dosage, a higher adsorption capacity was shown for $\mathrm{Cd}(\mathrm{II})\left(381.1 \mathrm{mg} \cdot \mathrm{g}^{-1}\right)$ than for $\mathrm{Hg}(\mathrm{II})\left(235.6 \mathrm{mg} \cdot \mathrm{g}^{-1}\right)$. The results revealed that $\mathrm{Cd}(\mathrm{II})$ was adsorbed because Cd(II) ions have greater affinity for XLAC.

3.4. Adsorption Isotherms. Adsorption isotherms can elucidate how the heavy metal ions interact with XLAC, enabling the study of the practical application of XLAC in wastewater treatment. The adsorption parameters were determined using the Langmuir and Freundlich isotherm models. The linear forms of the Langmuir and Freundlich isotherms are represented, respectively, by [24]

$$
\begin{aligned}
\frac{C_{e}}{q_{e}} & =\frac{1}{b q_{m}}+\frac{C_{e}}{q_{m}}, \\
\ln q_{e} & =\ln k_{f}+\frac{1}{n} \ln C_{e},
\end{aligned}
$$

where $C_{e}$ is the concentration of the metal ions at equilibrium $\left(\mathrm{mol} \cdot \mathrm{L}^{-1}\right), q_{e}$ is the amount adsorbed $\left(\mathrm{mg} \cdot \mathrm{g}^{-1}\right), q_{m}$ is the complete monolayer adsorption capacity $\left(\mathrm{mg}^{-1}\right), b$ is the Langmuir constant related to the adsorption capacity $\left(\mathrm{L} \cdot \mathrm{g}^{-1}\right)$, and $n$ and $k_{f}$ are the Freundlich constants.
Data on the $\mathrm{Cd}(\mathrm{II})$ and $\mathrm{Hg}(\mathrm{II})$ adsorption capacities of XLAC at different temperatures were evaluated and are shown in Figure 3(a); the adsorption parameters of the Langmuir and Freundlich isotherm models for each heavy metal are presented in Figures 3(b) and 3(c) and Table 3. Figure 3(a) shows that an increase in temperature enhanced the adsorption capacities for $\mathrm{Cd}(\mathrm{II})$ and $\mathrm{Hg}(\mathrm{II})$ ions. These results can be attributed to a swelling effect within the internal structure of XLAC caused by an elevated temperature in a certain range, facilitating the penetration of metal ions binding with functional groups on the surface and the overcoming of the energy barrier of adsorption. As observed in Table 3, the $R_{\mathrm{Cd}(\mathrm{II})}^{2}$ value of $0.9912\left(P\left(1.856 \times 10^{-5}\right)<\right.$ $0.01)$ for the Langmuir model is higher than that for the Freundlich model of $0.7347(P(0.0018)<0.01)$, and there was no significant difference in the adsorption of $\mathrm{Cd}(\mathrm{II})$ ions. The $R_{\mathrm{Hg}(\mathrm{II})}^{2}$ value of $0.9882\left(P\left(3.340 \times 10^{-5}\right)<0.01\right)$ for the Langmuir model is also higher than that for the Freundlich model of $0.8460(P(0.0059)<0.01)$, and no significant difference was found in the adsorption of $\mathrm{Hg}$ (II) ions. The experimental data for both $\mathrm{Cd}(\mathrm{II})$ and $\mathrm{Hg}$ (II) ion adsorption had better coefficient values and better fits with the Langmuir isotherm model than with the Freundlich isotherm model (Figures 3(b) and 3(c)). Additionally, comparison of the goodness-of-fit measures between the two different models showed that the Langmuir model yielded the lower standard error (SE) values, and the higher SE values of the Freundlich model indicated low predictive ability to describe Cd(II) and 


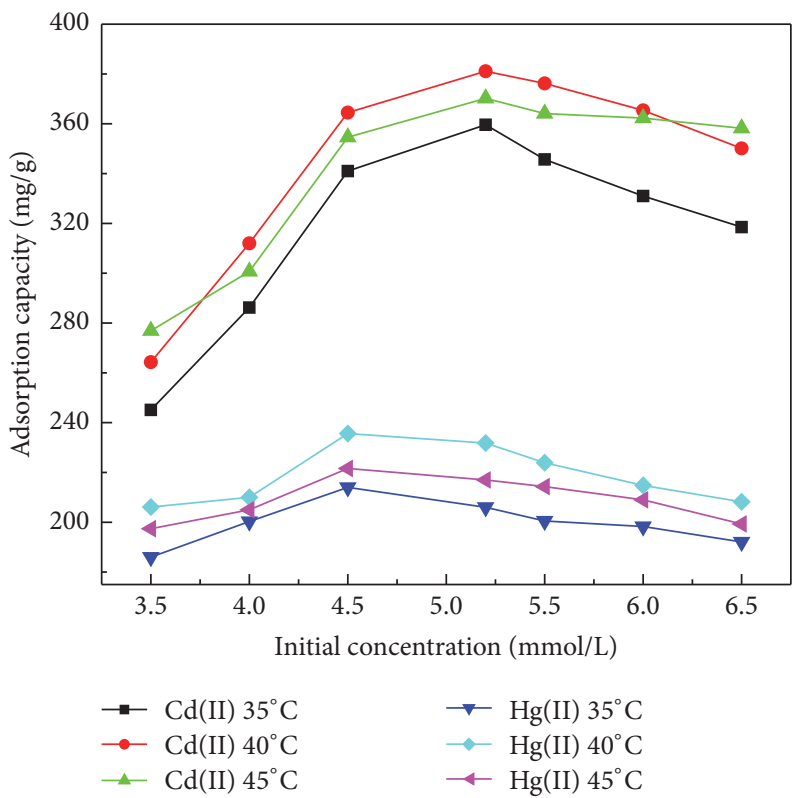

(a)

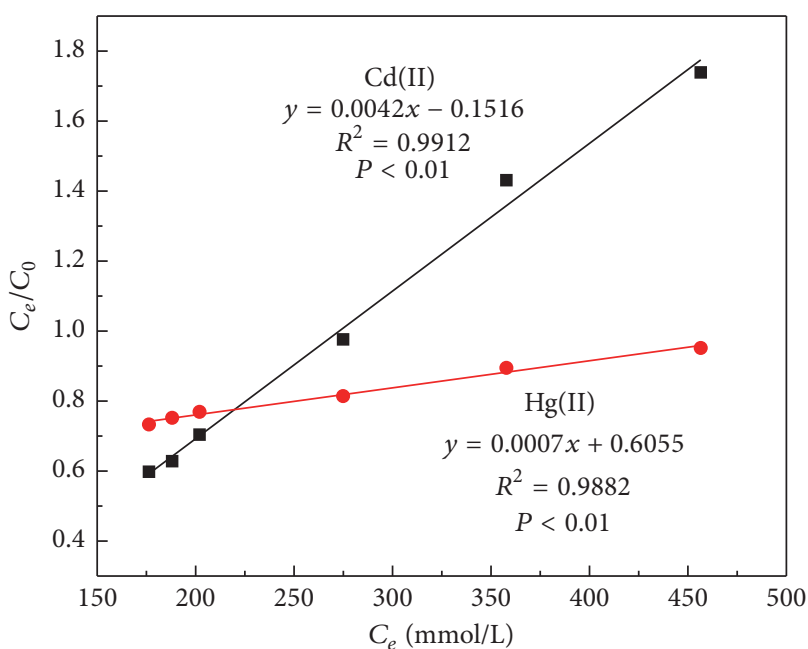

(b)

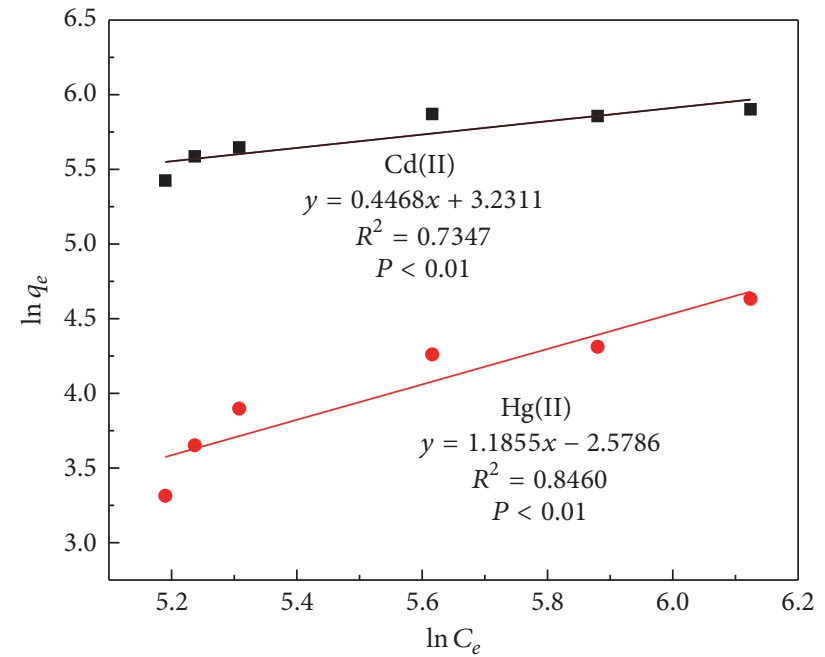

(c)

Figure 3: (a) Effects of the initial concentrations of $\mathrm{Cd}(\mathrm{II})$ and $\mathrm{Hg}(\mathrm{II})$ on the adsorption capacity of XLAC (adsorption experiments, $\mathrm{Cd}(\mathrm{II}): m=50 \mathrm{mg}, V=50 \mathrm{~mL}, \mathrm{pH}=5.5, T=35^{\circ} \mathrm{C}, 40^{\circ} \mathrm{C}$, and $45^{\circ} \mathrm{C}, t=300 \mathrm{~min}$, revolution rate $=200 \mathrm{revolutions} \cdot \mathrm{min}^{-1}$, and $C_{0(\mathrm{Cd}(\mathrm{II}))}$ ranged from 0.0035 to $0.0065 \mathrm{~mol} \cdot \mathrm{L}^{-1} ; \mathrm{Hg}(\mathrm{II}): m=50 \mathrm{mg}, V=50 \mathrm{~mL}, \mathrm{pH}=5.5, T=35^{\circ} \mathrm{C}, 40^{\circ} \mathrm{C}$, and $45^{\circ} \mathrm{C}, t=300 \mathrm{~min}$, revolution rate $=200$ revolutions $\cdot \mathrm{min}^{-1}$, and $C_{0(\mathrm{Hg}(\mathrm{II}))}$ ranged from 0.0035 to $\left.0.0065 \mathrm{~mol} \cdot \mathrm{L}^{-1}\right)$. (b) Langmuir equation fitting curves for $\mathrm{Cd}(\mathrm{II})$ and $\mathrm{Hg}(\mathrm{II})$ experimental data (adsorption experiments, $\mathrm{Cd}(\mathrm{II}): m=50 \mathrm{mg}, V=50 \mathrm{~mL}, C_{0(\mathrm{Cd}(\mathrm{II}))}=0.0052 \mathrm{~mol} \cdot \mathrm{L}^{-1}, \mathrm{pH}=5.5, T=40^{\circ} \mathrm{C}, t=300 \mathrm{~min}$, and revolution rate $=200$ revolutions $\cdot \mathrm{min}^{-1} ; \mathrm{Hg}(\mathrm{II}): m=50 \mathrm{mg}, V=50 \mathrm{~mL}, C_{0(\mathrm{Hg}(\mathrm{II}))}=0.0052 \mathrm{~mol} \cdot \mathrm{L}^{-1}, \mathrm{pH}=5.5, T=35^{\circ} \mathrm{C}, 40^{\circ} \mathrm{C}$, and $45^{\circ} \mathrm{C}$, $t=300 \mathrm{~min}$, and revolution rate $=200$ revolutions $\cdot \mathrm{min}^{-1}$ ). (c) Freundlich equation fitting curves for $\mathrm{Cd}(\mathrm{II})$ and $\mathrm{Hg}$ (II) experimental data (adsorption experiments, $\mathrm{Cd}(\mathrm{II}): m=50 \mathrm{mg}, V=50 \mathrm{~mL}, C_{0(\mathrm{Cd}(\mathrm{II}))}=0.0052 \mathrm{~mol} \cdot \mathrm{L}^{-1}, \mathrm{pH}=5.5, T=40^{\circ} \mathrm{C}, t=300 \mathrm{~min}$, and revolution rate $=200$ revolutions $\cdot \mathrm{min}^{-1} ; \mathrm{Hg}(\mathrm{II}): m=50 \mathrm{mg}, V=50 \mathrm{~mL}, C_{0(\mathrm{Hg}(\mathrm{II}))}=0.0052 \mathrm{~mol} \cdot \mathrm{L}^{-1}, \mathrm{pH}=5.5, \mathrm{~T}=35^{\circ} \mathrm{C}, 40^{\circ} \mathrm{C}$, and $45^{\circ} \mathrm{C}, t=300 \mathrm{~min}$, and revolution rate $=200$ revolutions $\cdot \mathrm{min}^{-1}$ ).

$\mathrm{Hg}(\mathrm{II})$ adsorption processes (Table 3 ). Therefore, the results for the single-metal-system solutions revealed that XLAC displayed higher affinity for $\mathrm{Cd}(\mathrm{II})$ than for $\mathrm{Hg}(\mathrm{II})$ ions [25]. The maximum monolayer adsorption capacity, $q_{m}\left(\mathrm{mg} \cdot \mathrm{g}^{-1}\right)$, derived from the experimental data reached $388.7 \mathrm{mg} \cdot \mathrm{g}^{-1}$ for $\mathrm{Cd}(\mathrm{II})$ and $235.6 \mathrm{mg} \cdot \mathrm{g}^{-1}$ for $\mathrm{Hg}$ (II) ions. The adsorption capacities of XLAC for $\mathrm{Cd}(\mathrm{II})$ and $\mathrm{Hg}$ (II) ions were found to be comparable and moderately higher than those of other 
TABLE 3: Langmuir and Freundlich isotherm parameters for the adsorption of Cd(II) and $\mathrm{Hg}(\mathrm{II})$ on XLAC in single-metal systems (adsorption experiments, $\mathrm{Cd}(\mathrm{II}): m=50 \mathrm{mg}, V=50 \mathrm{~mL}, C_{0(\mathrm{Cd}(\mathrm{II}))}=0.0052 \mathrm{~mol} \cdot \mathrm{L}^{-1}, \mathrm{pH}=5.5, T=40^{\circ} \mathrm{C}, t=300 \mathrm{~min}$, and revolution rate $=200$ revolutions $\cdot \mathrm{min}^{-1} ; \mathrm{Hg}(\mathrm{II}): m=50 \mathrm{mg}, V=50 \mathrm{~mL}, C_{0(\mathrm{Hg}(\mathrm{II}))}=0.0052 \mathrm{~mol} \cdot \mathrm{L}^{-1}, \mathrm{pH}=5.5, T=35^{\circ} \mathrm{C}, 40^{\circ} \mathrm{C}$, and $45^{\circ} \mathrm{C}, t=300 \mathrm{~min}$, and revolution rate $=200$ revolutions $\left.\cdot \mathrm{min}^{-1}\right)$.

\begin{tabular}{lcccccrrrrr}
\hline \multirow{2}{*}{ System } & \multicolumn{4}{c}{ Langmuir isotherm model } & \multicolumn{4}{c}{ Freundlich isotherm model } \\
& $b$ & $q_{m}\left(\mathrm{mg}^{-1} \mathrm{~g}^{-1}\right)$ & $R^{2}$ & $\mathrm{SE}$ & $P$ & $K_{f}\left(\mathrm{~mol} \cdot \mathrm{g}^{-1}\right)$ & $n$ & $R^{2}$ & $\mathrm{SE}$ & $P$ \\
\hline $\mathrm{Cd}(\mathrm{II})$ & 0.0146 & 388.7 & 0.9912 & $1.775 \times 10^{-4}$ & $1.856 \times 10^{-5}$ & 94.8883 & 1.9487 & 0.7347 & 0.0160 & 0.0018 \\
$\mathrm{Hg}(\mathrm{II})$ & 0.2462 & 235.6 & 0.9882 & $3.774 \times 10^{-5}$ & $3.340 \times 10^{-5}$ & 134.0617 & 6.0716 & 0.8460 & 0.0221 & 0.0059 \\
\hline
\end{tabular}

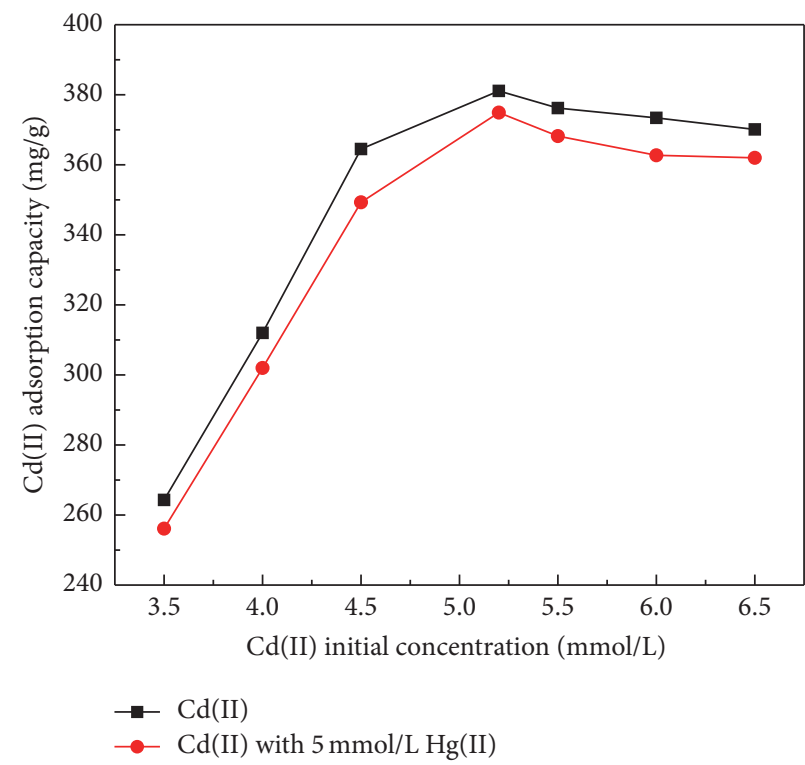

(a)

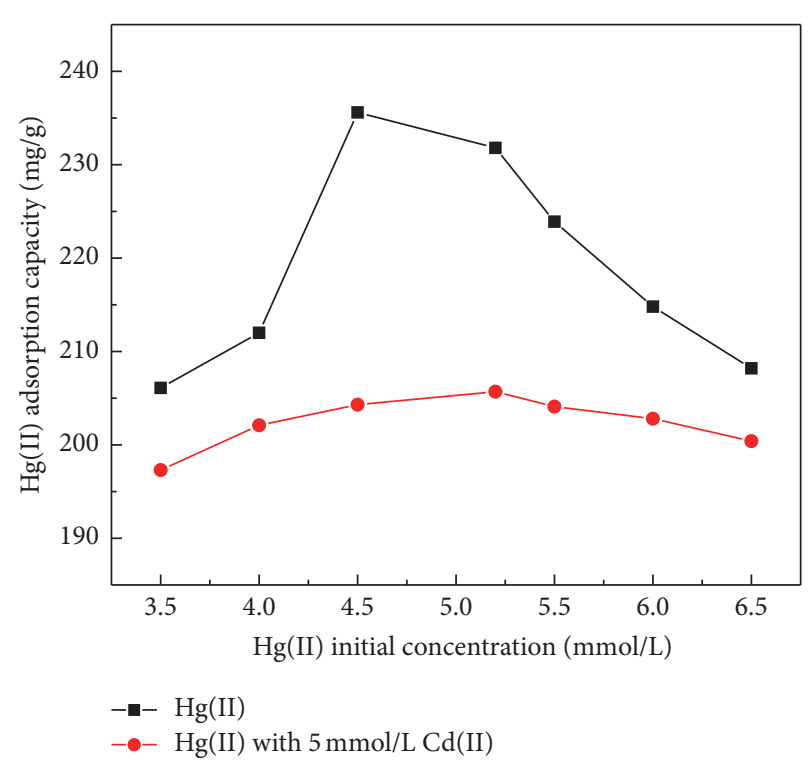

(b)

Figure 4: (a) Adsorption of Cd(II) on XLAC in binary metal systems (adsorption experiments, $m=50 \mathrm{mg}, V=50 \mathrm{~mL}, \mathrm{pH}=5.5, T=40^{\circ} \mathrm{C}$, $t=300 \mathrm{~min}$, revolution rate $=200$ revolutions $\cdot \mathrm{min}^{-1}, C_{0(\mathrm{Hg}(\mathrm{II}))}=0.005 \mathrm{~mol} \cdot \mathrm{L}^{-1}$, and $C_{0(\mathrm{Cd}(\mathrm{II}))}$ ranged from 0.0035 to $\left.0.0065 \mathrm{~mol} \cdot \mathrm{L}^{-1}\right) .(\mathrm{b})$ Adsorption of $\mathrm{Hg}(\mathrm{II})$ on XLAC in binary metal systems (adsorption experiments, $m=50 \mathrm{mg}, V=50 \mathrm{~mL}, \mathrm{pH}=5.5, T=40^{\circ} \mathrm{C}, t=300 \mathrm{~min}$, revolution rate $=200$ revolutions $\cdot \mathrm{min}^{-1}, C_{0(\mathrm{Cd}(\mathrm{II}))}=0.005 \mathrm{~mol} \cdot \mathrm{L}^{-1}$, and $C_{0(\mathrm{Hg}(\mathrm{II}))}$ ranged from 0.0035 to $\left.0.0065 \mathrm{~mol} \cdot \mathrm{L}^{-1}\right)$.

similar reported adsorbents [26]. XLAC has considerable potential for the removal of $\mathrm{Cd}(\mathrm{II})$ and $\mathrm{Hg}(\mathrm{II})$ ions from wastewater, with stronger affinity for Cd(II) ions.

3.5. Competitive Adsorption. The competitive adsorption characteristics of $\mathrm{Cd}(\mathrm{II})$ and $\mathrm{Hg}(\mathrm{II})$ ions in binary metal solution systems were investigated, and the results are shown in Figure 4. When $\mathrm{Hg}(\mathrm{II})$ ions were added to the system at an initial concentration of $0.005 \mathrm{~mol} \cdot \mathrm{L}^{-1}$, the adsorption capacity for $\mathrm{Cd}$ (II) increased with increasing initial Cd(II) concentration and gradually reached adsorption equilibrium (Figure 4(a)). These results imply that the Cd(II) adsorption capacity of XLAC was similar in single-metal and binary metal systems and did not experience competition after the addition of $\mathrm{Hg}$ (II). In contrast, the $\mathrm{Hg}$ (II) ion adsorption capacity of XLAC was affected by the presence of $\mathrm{Cd}(\mathrm{II})$ at an initial concentration of $0.005 \mathrm{~mol} \cdot \mathrm{L}^{-1}$ (Figure $4(\mathrm{~b})$ ). This finding indicates that activated sites for $\mathrm{Cd}(\mathrm{II})$ on XLAC may be partially occupied by the added $\mathrm{Hg}$ (II) in binary systems, but when the concentration of $\mathrm{Cd}(\mathrm{II})$ ions in solution was increased, Cd(II) was adsorbed preferentially at the adsorption sites on the XLAC surface, particularly in the case of insufficient activated sites [27]. At low metal concentrations, the number of available adsorption sites was sufficient. Hence, the adsorption capacity of XLAC was not influenced by the presence of other heavy metal ions. However, when the concentration of metals exceeded the adsorption capacity, Cd(II) was adsorbed preferentially in the binary metal solution over the $\mathrm{Hg}(\mathrm{II})$ ions. This phenomenon suggests that $\mathrm{Cd}$ (II) ions have higher affinity for XLAC, which may be attributed to the fact that a longer ionic radius (Cd(II) $(97 \mathrm{pm})<\mathrm{Hg}$ (II) $(110 \mathrm{pm}))$ corresponds to a shorter hydrated ionic radius, resulting in the higher affinity for metal ions of the activated sites of XLAC. Furthermore, the arrangements of the extranuclear electrons of $\mathrm{Cd}(\mathrm{II})$ and $\mathrm{Hg}$ (II) ions are $4 d^{10} 5 s^{0}$ and $5 d^{10} 6 s^{0}$, respectively. According to $\mathrm{Xu}$ Guangxian's Approximate Rule of Electronic Configuration [28], the energy level of the nuclear track of $5 s^{0}$ is lower than that of $6 s^{0}$; thus, as the $-\mathrm{OH},-\mathrm{C}=\mathrm{O}$, and $-\mathrm{NH}$ functional groups on XLAC reacted with metal ions, the lone-electronpair electron clouds around the $\mathrm{O}$ and $\mathrm{N}$ atoms could 


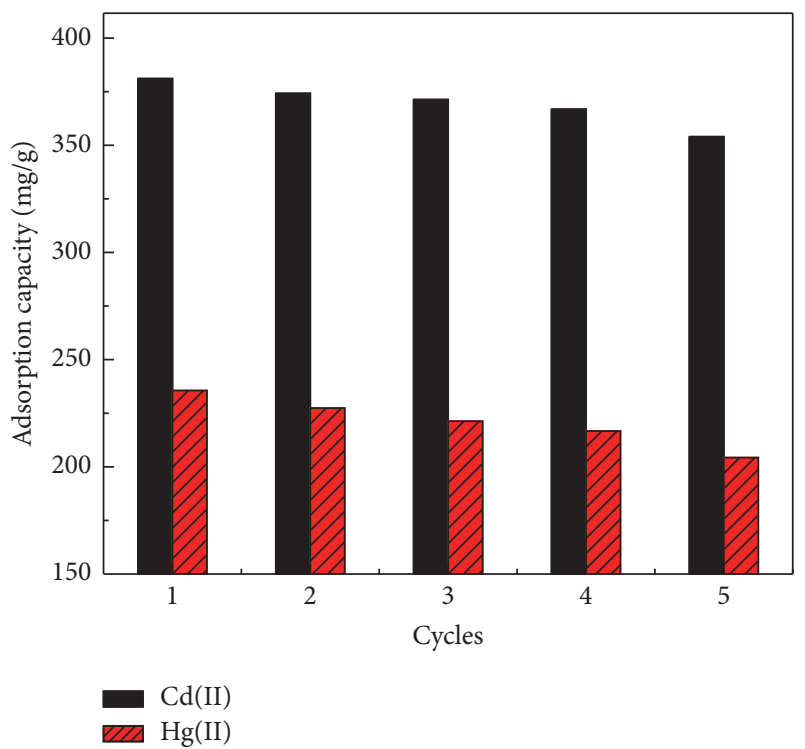

FIGURE 5: Adsorption and desorption of Cd(II) and $\mathrm{Hg}$ (II) on XLAC (desorption experiments, Cd(II): Cd-loaded-XLAC dose $=50 \mathrm{mg}$, $V=50 \mathrm{~mL}, \mathrm{HNO}_{3}$ concentration $=0.01 \mathrm{~mol} \cdot \mathrm{L}^{-1}, T=25^{\circ} \mathrm{C}, t=$ $120 \mathrm{~min}$, and revolution rate $=200$ revolutions $\cdot \mathrm{min}^{-1} ; \mathrm{Hg}(\mathrm{II}): \mathrm{Hg}-$ loaded-XLAC dose $=50 \mathrm{mg}, V=50 \mathrm{~mL}, \mathrm{HNO}_{3}$ concentration = $0.01 \mathrm{~mol} \cdot \mathrm{L}^{-1}, T=25^{\circ} \mathrm{C}, t=120 \mathrm{~min}$, and revolution rate $=200$ revolutions $\cdot \min ^{-1}$ ).

first fill the lower energy level, $5 s^{0}$. Hence, the adsorption capacity of XLAC for Cd(II) remained the same as that in the single-metal solutions, but the competitive adsorption had a negative influence on $\mathrm{Hg}(\mathrm{II})$ ions. Similar results have been observed in other studies [29].

3.6. Regeneration Studies. The regeneration of XLAC after adsorption is one of the key factors for its economic viability in practical applications for wastewater treatment. Reusability studies were conducted to regenerate heavy metals loaded on XLAC [30]. $\mathrm{HNO}_{3}$ at a concentration of $0.01 \mathrm{~mol} \cdot \mathrm{L}^{-1}$ was selected as the eluent for desorption of $\mathrm{Cd}(\mathrm{II})$ and $\mathrm{Hg}$ (II) ions from XLAC. Figure 5 shows the adsorptiondesorption results for the two metals and the regeneration of XLAC for five consecutive cycles. The reusability results for XLAC suggest that the adsorption capacities for Cd(II) and $\mathrm{Hg}$ (II) ions were almost unaffected, even after four cycles. The decrease in the adsorption capacity for the two metals was determined to be $20 \mathrm{mg} \cdot \mathrm{g}^{-1}$ before the fifth use. This trend might be responsible for the negligible amount of materials lost during the regeneration cycles. In summary, XLAC can be used repeatedly for four cycles with little loss of initial adsorption capacity and possesses good regenerative properties towards $\mathrm{Cd}(\mathrm{II})$ and $\mathrm{Hg}(\mathrm{II})$ ions in wastewater.

\section{Conclusions}

XLAC was developed through $\mathrm{H}_{3} \mathrm{PO}_{4}$ activation from $X$. sorbifolia Bunge hull and in 34\% yields. XLAC was characterized using BET, SEM, EDX, and FTIR analysis.
The maximum adsorption capacities were $388.7 \mathrm{mg} \cdot \mathrm{g}^{-1}$ for $\mathrm{Cd}(\mathrm{II})$ and $235.6 \mathrm{mg} \cdot \mathrm{g}^{-1}$ for $\mathrm{Hg}$ (II) under the optimum conditions of adsorbent dosage of $50 \mathrm{mg}, \mathrm{pH}$ of 5.5, and temperature of $45^{\circ} \mathrm{C}$. The adsorption equilibria of both $\mathrm{Cd}(\mathrm{II})$ and $\mathrm{Hg}(\mathrm{II})$ ions were described successfully by Langmuir isotherm models. Competitive adsorption results revealed that $\mathrm{Cd}(\mathrm{II})$ ions had higher adsorption affinity than $\mathrm{Hg}(\mathrm{II})$ ions did with activated sites on the XLAC surface. FTIR spectroscopic analysis of metal-loaded XLAC confirmed that the adsorption process occurred through chemical ion exchange.

XLAC was effectively regenerated using $0.01 \mathrm{~mol} \cdot \mathrm{L}^{-1}$ $\mathrm{HNO}_{3}$ as the agent and was reused and showed high performance after four adsorption-desorption cycles. XLAC can be used as a low-cost, alternative adsorbent for the treatment of wastewater containing $\mathrm{Cd}(\mathrm{II})$ and $\mathrm{Hg}(\mathrm{II})$ ions.

\section{Competing Interests}

The authors declare that they have no competing interests.

\section{Authors' Contributions}

Xiaotao Zhang and Yinan Hao contributed equally to this paper.

\section{Acknowledgments}

This work was supported by the National Natural Science Foundation of China (NSFC 21467021); the Disposal and Recycling Technology Development and Industrialization Demonstration of Industrial Solid Waste of the Inner Mongolia Autonomous Region (20131506); the Transformation Fund for Science and Technology Achievements of Inner Mongolia Agricultural University (CGZH 2014009); the Innovation Team of Desert Shrub Fibrosis and Energy Utilization Technology of the Inner Mongolia Autonomous Region; the Innovation Team of Desert Shrub Fibrosis Energy Development and Utilization of Science and Technology of the Inner Mongolia Autonomous Region; and the Talent Development Fund of Inner Mongolia.

\section{References}

[1] A. Ahmad, R. Ghufran, and W. M. Faizal, "Cd(II), Pb(II) and $\mathrm{Zn}$ (II) removal from contaminated water by biosorption using activated sludge biomass," Clean-Soil, Air, Water, vol. 38, no. 2, pp. 153-158, 2010.

[2] M. M. Montazer-Rahmati, P. Rabbani, A. Abdolali, and A. R. Keshtkar, "Kinetics and equilibrium studies on biosorption of cadmium, lead, and nickel ions from aqueous solutions by intact and chemically modified brown algae," Journal of Hazardous Materials, vol. 185, no. 1, pp. 401-407, 2011.

[3] M. A. Barakat, "New trends in removing heavy metals from industrial wastewater," Arabian Journal of Chemistry, vol. 4, no. 4, pp. 361-377, 2011.

[4] G. Prakash Williams, M. Gnanadesigan, and S. Ravikumar, "Biosorption and bio-kinetic studies of halobacterial strains 
against $\mathrm{Ni}^{2+}, \mathrm{Al}^{3+}$ and $\mathrm{Hg}^{2+}$ metal ions," Bioresource Technology, vol. 107, pp. 526-529, 2012.

[5] A. M. Donia, A. A. Atia, and A. M. Heniesh, "Efficient removal of $\mathrm{Hg}$ (II) using magnetic chelating resin derived from copolymerization of bisthiourea/thiourea/glutaraldehyde," Separation and Purification Technology, vol. 60, no. 1, pp. 46-53, 2008.

[6] C. Sun, J. Qiu, Z. Zhang, T. F. Marhaba, and Y. Zhang, "Removal of arsenite from Water by Ce-Al-Fe trimetal oxide adsorbent: kinetics, isotherms, and thermodynamics," Journal of Chemistry, vol. 2016, Article ID 8617219, 8 pages, 2016.

[7] R. Zein, R. Suhaili, F. Earnestly, Indrawati, and E. Munaf, "Removal of $\mathrm{Pb}(\mathrm{II}), \mathrm{Cd}(\mathrm{II})$ and $\mathrm{Co}(\mathrm{II})$ from aqueous solution using Garcinia mangostana L. fruit shell," Journal of Hazardous Materials, vol. 181, no. 1-3, pp. 52-56, 2010.

[8] H.-C. Tao, H.-R. Zhang, J.-B. Li, and W.-Y. Ding, "Biomass based activated carbon obtained from sludge and sugarcane bagasse for removing lead ion from wastewater," Bioresource Technology, vol. 192, pp. 611-617, 2015.

[9] B. Buczek, "Preparation of active carbon by additional activation with potassium hydroxide and characterization of their properties," Advances in Materials Science and Engineering, vol. 2016, Article ID 5819208, 4 pages, 2016.

[10] A. Aygün, S. Yenisoy-Karakaş, and I. Duman, "Production of granular activated carbon from fruit stones and nutshells and evaluation of their physical, chemical and adsorption properties," Microporous and Mesoporous Materials, vol. 66, no. 2-3, pp. 189-195, 2003.

[11] S. Mopoung, P. Moonsri, W. Palas, and S. Khumpai, "Characterization and properties of activated carbon prepared from tamarind seeds by koh activation for fe(III) adsorption from aqueous solution," The Scientific World Journal, vol. 2015, Article ID 415961, 9 pages, 2015.

[12] L. Wang, "Application of activated carbon derived from 'waste' bamboo culms for the adsorption of azo disperse dye: kinetic, equilibrium and thermodynamic studies," Journal of Environmental Management, vol. 102, pp. 79-87, 2012.

[13] H. Treviño-Cordero, L. G. Juárez-Aguilar, D. I. MendozaCastillo, V. Hernández-Montoya, A. Bonilla-Petriciolet, and M. A. Montes-Morán, "Synthesis and adsorption properties of activated carbons from biomass of prunus domestica and jacaranda mimosifolia for the removal of heavy metals and dyes from water," Industrial Crops and Products, vol. 42, no. 1, pp. 315323, 2013.

[14] G.-G. Choi, S.-J. Oh, S.-J. Lee, and J.-S. Kim, "Production of bio-based phenolic resin and activated carbon from bio-oil and biochar derived from fast pyrolysis of palm kernel shells," Bioresource Technology, vol. 178, pp. 99-107, 2015.

[15] X.-J. Guo, D.-H. Yuan, Q. Li, J.-Y. Jiang, F.-X. Chen, and H. Zhang, "Spectroscopic techniques for quantitative characterization of $\mathrm{Cu}$ (II) and $\mathrm{Hg}$ (II) complexation by dissolved organic matter from lake sediment in arid and semi-arid region," Ecotoxicology and Environmental Safety, vol. 85, pp. 144-150, 2012.

[16] F. Granados-Correa and S. Bulbulian, "Co(II) adsorption in aqueous media by a synthetic Fe-Mn binary oxide adsorbent," Water, Air, \& Soil Pollution, vol. 223, no. 7, pp. 4089-4100, 2012.

[17] A. S. Luna, A. L. H. Costa, A. C. A. da Costa, and C. A. Henriques, "Competitive biosorption of cadmium(II) and zinc(II) ions from binary systems by Sargassum filipendula," Bioresource Technology, vol. 101, no. 14, pp. 5104-5111, 2010.

[18] M. V. Lopez-Ramon, F. Stoeckli, C. Moreno-Castilla, and F. Carrasco-Marin, "On the characterization of acidic and basic surface sites on carbons by various techniques," Carbon, vol. 37, no. 8, pp. 1215-1221, 1999.

[19] M. Benadjemia, L. Millière, L. Reinert, N. Benderdouche, and L. Duclaux, "Preparation, characterization and Methylene Blue adsorption of phosphoric acid activated carbons from globe artichoke leaves," Fuel Processing Technology, vol. 92, no. 6, pp. 1203-1212, 2011.

[20] G. Tan and D. Xiao, "Adsorption of cadmium ion from aqueous solution by ground wheat stems," Journal of Hazardous Materials, vol. 164, no. 2-3, pp. 1359-1363, 2009.

[21] L. V. A. Gurgel, O. K. Júnior, R. P. D. F. Gil, and L. F. Gil, “Adsorption of $\mathrm{Cu}(\mathrm{II}), \mathrm{Cd}(\mathrm{II})$, and $\mathrm{Pb}(\mathrm{II})$ from aqueous single metal solutions by cellulose and mercerized cellulose chemically modified with succinic anhydride," Bioresource Technology, vol. 99, no. 8, pp. 3077-3083, 2008.

[22] G. Müller, C. Schöpper, H. Vos, A. Kharazipour, and A. Polle, "FTIR-ATR spectroscopic analyses of changes in wood properties during particle- and fibreboard production of hardand softwood trees," BioResources, vol. 4, no. 1, pp. 49-71, 2009.

[23] T. Fan, Y. Liu, B. Feng et al., "Biosorption of cadmium(II), zinc(II) and lead(II) by Penicillium simplicissimum: isotherms, kinetics and thermodynamics," Journal of Hazardous Materials, vol. 160, no. 2-3, pp. 655-661, 2008.

[24] K. Periasamy and C. Namasivayam, "Removal of nickel(II) from aqueous solution and nickel plating industry wastewater using an agricultural waste: peanut hulls," Waste Management, vol. 15, no. 1, pp. 63-68, 1995.

[25] A. Bogusz, P. Oleszczuk, and R. Dobrowolski, "Application of laboratory prepared and commercially available biochars to adsorption of cadmium, copper and zinc ions from water," Bioresource Technology, vol. 196, pp. 540-549, 2015.

[26] H. J. Shipley, K. E. Engates, and V. A. Grover, "Removal of Pb(II), $\mathrm{Cd}(\mathrm{II}), \mathrm{Cu}(\mathrm{II})$, and $\mathrm{Zn}(\mathrm{II})$ by hematite nanoparticles: effect of sorbent concentration, $\mathrm{pH}$, temperature, and exhaustion," Environmental Science and Pollution Research, vol. 20, no. 3, pp. 1727-1736, 2013.

[27] R. Apiratikul and P. Pavasant, "Sorption isotherm model for binary component sorption of copper, cadmium, and lead ions using dried green macroalga, Caulerpa lentillifera," Chemical Engineering Journal, vol. 119, no. 2-3, pp. 135-145, 2006.

[28] L. Liu and B. Zhu, "Xu Guang-Xian approximate rule of electronic configuration and its application," Journal of Chemical Education, vol. 37, no. 2, pp. 14-17, 2016.

[29] A. Sari, D. Mendil, M. Tuzen, and M. Soylak, "Biosorption of $\mathrm{Cd}$ (II) and $\mathrm{Cr}$ (III) from aqueous solution by moss (Hylocomium splendens) biomass: equilibrium, kinetic and thermodynamic studies," Chemical Engineering Journal, vol. 144, no. 1, pp. 1-9, 2008.

[30] B. Yu, Y. Zhang, A. Shukla, S. S. Shukla, and K. L. Dorris, "The removal of heavy metals from aqueous solutions by sawdust adsorption-removal of lead and comparison of its adsorption with copper," Journal of Hazardous Materials, vol. 84, no. 1, pp. 83-94, 2001. 

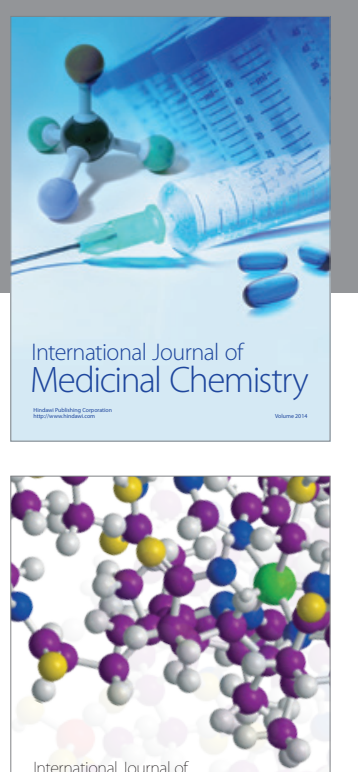

Carbohydrate Chemistry

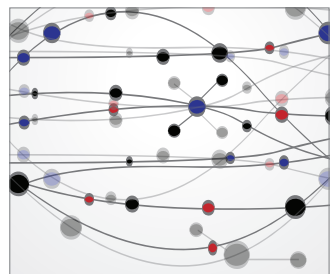

The Scientific World Journal
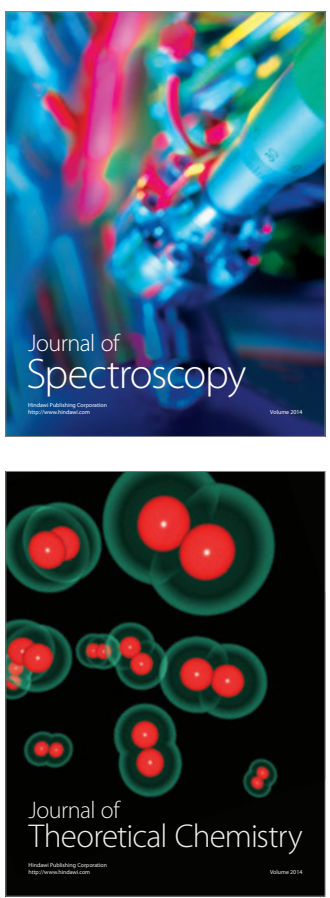
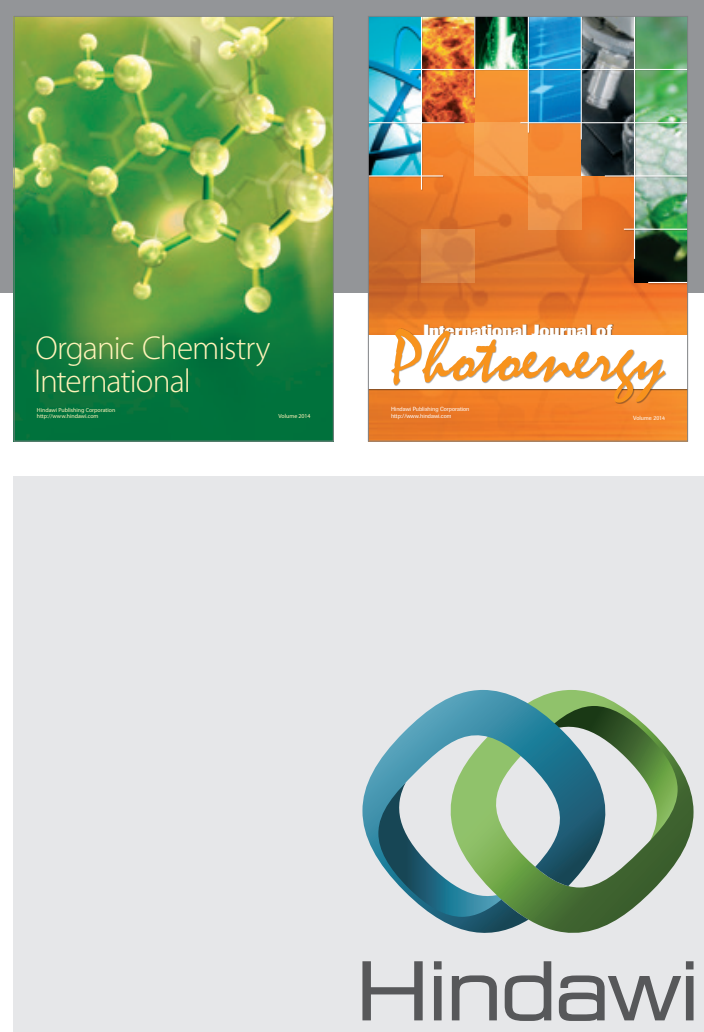

Submit your manuscripts at

http://www.hindawi.com

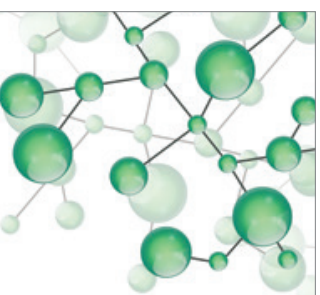

International Journal of

Inorganic Chemistry

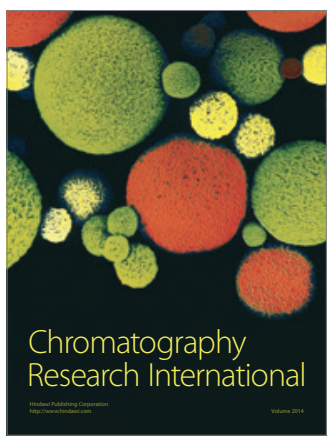

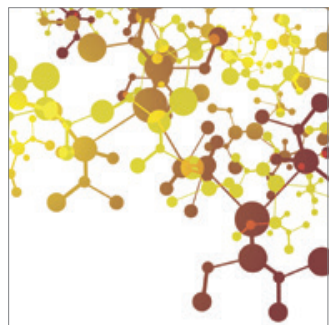

Applied Chemistry
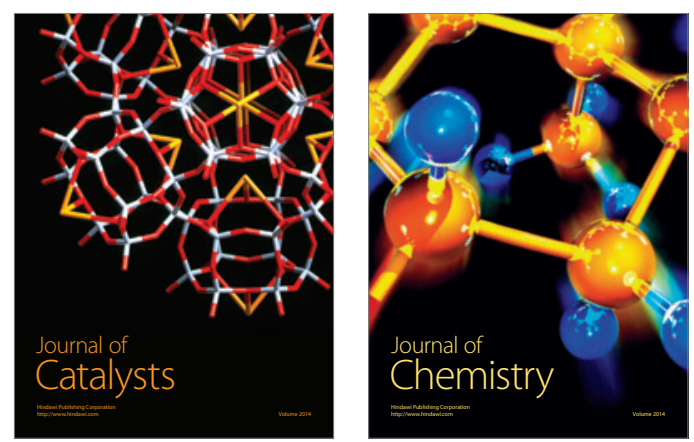
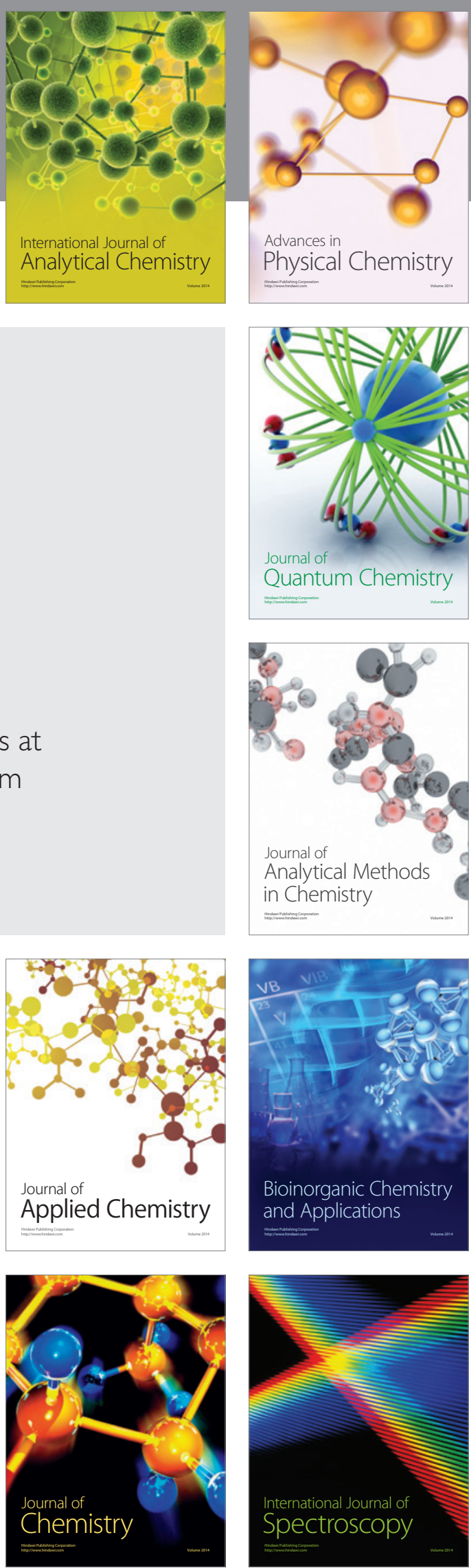